Brito, Joás ${ }^{1 *}$; Calvão, Lenize ${ }^{234}$; Cunha, Erlane ${ }^{12}$; Maioli, Leandro ${ }^{5}$; Barbirato, Mayla ${ }^{5}$; Rolim, Samir ${ }^{6}$, Juen Leandro ${ }^{13}$

\title{
Environmental variables affect the diversity of adult damselflies (Odonata: Zygoptera) in western Amazonia
}

https://doi.org/10.23797/2159-6719_24_8

Received: 22 September 2020 - Accepted: 27 December 2020 - Published: 7 July 2021

\begin{abstract}
Our study evaluated the effects of environmental variables on the assemblages of the suborder Zygoptera, and tested the hypothesis that environmental variables are more important determinants of the structure of these assemblages than limnological variables in streams. We sampled 17 streams in the Carajás National Forest and tested our hypothesis using a linear regression analysis, with the zygopteran species composition, richness, and abundance as the response variables. Our findings indicate that both limnological and physical variables influence, independently, the characteristics of the zygopteran assemblages. The riparian forest maintains the stability of the environment and provides dispersal corridors, along which the zygopterans can reach alternative, suitable environments. The small scale of this study also implies that the continuity of the vegetation is essential for the dispersal of the zygopterans among different landscapes. The high levels of abundance recorded in the better-preserved environments may reflect the maintenance of specific habitats and resource availability. Riparian forest is crucial to the ecological equilibrium of the stream systems, although further research at a broader spatial scale that focuses on a greater diversity of variables should provide more robust insights into the phenomenon.
\end{abstract}

Keywords: dragonfly, aquatic insects, connectivity, stream ecology, habitat integrity

\section{Introduction}

The distribution of aquatic insects has often been explained in terms of the influence of the physical structure of the habitat and the chemical composition of the water (Heino et al., 2005; Landeiro et al., 2011; Landeiro et al., 2012; Cunha et al., 2015). In their seminal work, McArthur \& McArthur (1961) proposed that habitat heterogeneity and its physical components have an important influence on the characteristics of the community, providing the physical conditions and resources required by the organisms to survive in the environment. The structural components of stream systems, such as woody and leafy debris, shape the distribution of their aquatic fauna (i.e., fish and benthonic invertebrates), creating a heterogeneous gradient that determines the variation in the breeding and foraging patterns of different organisms (MacArthur \& MacArthur, 1961; Thomaz \& Cunha, 2010; Kovalenko et al., 2012). Environmental factors, such as ambient temperatures, the chemical compounds dissolved in the water, and its turbidity, may also be important, functioning as environmental filters, to determine which species inhabit a given environment (Oliveira Júnior et al., 2015; Brasil et al., 2018).

In the Amazon rainforest, the principal impacts on stream systems are derived from human activities, in particular, cash cropping (Cunha et al., 2015), cattle ranching, logging (Calvão et al., 2016), hydroelectric dams, and mining (Monteiro, 2005; Fearnside, 2006; Luiza-Andrade et al., 2020), all of which may influence the physical structure of the stream margins and the quality of the water, which affect

1 Graduate Program in Ecology, Federal University of Pará, Belém, Brazil,

2 Laboratory of Ecology and Conservation, Federal University of Pará, Belém, Brazil, e-mail-address: lenizecalvaodagmail.com, erlanejcunhalagmail.com

3 Laboratory of Ecology and Conservation, Federal University of Pará, Belém, Brazil, email-address: leandrojuenagmail.com

4 Graduate Program in Environmental Sciences (PPGCA), Federal University of Amapá

5 Vale S.A., North and South Sierras Environmental Management, e-mail address: leandro.maioli@vale. com, mayla.barbiratoßvale.com

6 Project Coordination, Amplo Engineering and Project Management Ltd., e-mail address: samir.rolima amploengenharia.com.br

* corresponding author E-mail: jotabio13agmail.com 
the stability of the environmental (Nessimian et al., 2008; Brasil et al., 2014a; Cunha et al., 2015; Oliveira Júnior et al., 2015). Mining is widespread in the Amazon region, and can have a significant impact on many of the natural characteristics of the stream systems (Callisto et al., 1998). Mining may also affect specific features of the water, such as its $\mathrm{pH}$ and the concentrations of some chemical compounds, and any change in the input of energy may have unpredictable consequences for the resident fauna (Callisto et al., 1998; Enríquez-Espinosa et al., 2020). In Brazil, mining operations are covered by specific environmental legislation (federal law 12,561/2012), which legislates the preservation of the riparian vegetation of the streams within the area affected by the activity (Soares-Filho et al., 2014).

One of the principal impacts on stream systems is the removal of the riparian vegetation (Lampert \& Sommer, 2007; Nessimian et al., 2008; Brasil et al., 2014b). Nessimian et al. (2008) proposed the Habitat Integrity Index (HII), which quantifies the stability and integrity of this vegetation, and provides a systematic estimate of its physical structure. The riparian vegetation plays a vital role as a saturation zone, by controlling the input of sediments into the stream bottom (Callisto et al., 2001; Astudillo et al., 2016), and maintaining the equilibrium of the environment by regulating air and water temperatures, the incidence of sunlight, shading, and the input of the allochthonous materials that support the system's trophic webs (Maloney \& Weller, 2011; Oliveira Júnior et al., 2015; Monteiro-Júnior et al., 2015; Carvalho et al., 2018).

Environmental disequilibrium caused by the suppression of the riparian vegetation may have a major impact on the fauna of aquatic systems (Nessimian et al., 2008). A number of ecological studies have demonstrated that these impacts harm the natural assemblages found in the aquatic systems (Brasil et al., 2014a; Oliveira Júnior et al., 2015; Siquiera et al., 2015; Astudillo et al., 2016; Carvalho et al., 2018), in particular, by decreasing both species diversity and abundance. The removal of the riparian vegetation impacts environmental stability primarily by altering ambient temperatures, water quality, and the shade provided by the vegetation (Carvalho et al., 2013). Impacts on the riparian vegetation also modify the connectivity between streams, which alters dispersal patterns and the distribution of organisms at both local and regional levels (Carvalho et al., 2013; Heino, 2013; Monteiro Júnior et al., 2015; Tonkin et al., 2017).

The suborder Zygoptera (Odonata; Insecta) comprises insects that are primarily specialists adapted for specific environmental conditions, typically within a narrow range (Corbet \& May, 2008; Oliveira Júnior et al., 2015). Corbet (1999) classified most zygopteran adults as thermal conformers, with a high thermal conductance, which means that their body temperature is determined by their immediate environment. Thermal conformers may be affected profoundly by modifications in the riparian forest, and are thus considered to be habitat specialists, which supports their role as bioindicators of environmental impact (Oliveira Júnior et al., 2015; Calvão et al., 2016). In most cases, zygopteran species richness and abundance are reduced, and in extreme cases, local extinctions may occur (Oliveira Júnior et al., 2015; Brasil et al., 2018; Mafuwe \& Moyo, 2020). Even when the riparian forest is not affected directly by the anthropogenic impact, the conditions of the surrounding matrix may also be important for the dispersal of the insects beyond the riparian zone (Calvão et al., 2016), which creates a habitat gradient that the species need to traverse (Dolný et al., 2014). In this scenario, modifications in ambient temperatures or the vegetation cover over the streams would have negative impacts on adult zygopterans, which require very specific conditions (Corbet, 1999; Monteiro Júnior et al., 2015). Understanding the influence of environmental factors and connectivity on the dynamics of stream assemblages is a fundamental objective in aquatic ecology. Adult zygopterans are good models for the assessment of anthropogenic impacts (Oliveira Júnior \& Juen, 2019) through the assessment of dispersal patterns in relation to specific environmental interruptions (Carvalho et al., 2013; Juen et al., 2014; Oliveira Júnior et al., 2015).

In the present study, we evaluated the role of physical variables, based on the HII and the features of the nearest mining site (pit size and distance), and limnological variables on the characteristics of the zygopteran assemblages observed at the sampling sites, located in stream systems in the Carajás National Forest, in northern Brazil. We hypothesized that elements of the physical structure structure of the streams are more effective drivers of zygopteran diversity (species composition, richness, and abundance) than limnological variables, such as dissolved gases and solids. In this case, the HII provides a surrogate of physical structure, and higher HII scores indicate better preserved sites with a high degree of environmental equilibrium, which is essential for the maintenance of diversity in both the streams and the surrounding habitats. In general, the integrity of streams will decline with increasing proximity to mining operations (Enríquez-Espinosa et al., 2020). 


\section{Materials and Methods}

\section{Study area}

This study was conducted in the Carajás National Forest, in southeastern Pará state, northern Brazil $\left(06^{\circ} 0^{\prime} 00^{\prime} \mathrm{S}, 50^{\circ} 24^{\prime} 0^{\prime}\right.$ ' W; Figure 1). This region has a humid tropical climate with dry winters, classified as $A W i$ in the Köppen system (Peel et al., 2007). More than 95\% of this conservation unit is covered by dense hardwood forests, with the remaining area consisting of a type of savanna, known locally as the "canga", which grows on soils rich in iron-ore, and is referred to as the Iron Triangle (Ab’Saber, 1986; Luiza-Andrade et al., 2020). The rainy season lasts from November to May, and the dry season, from June to October, with total annual precipitation of 1800-2300 mm (Moraes et al., 2005). The study area is 400-900 $\mathrm{m}$ above sea level (a.s.l.), and contrast with the surrounding area, which has altitudes of between $80 \mathrm{~m}$ and $300 \mathrm{~m}$ a.s.l. (Soares-Filho et al., 2014).

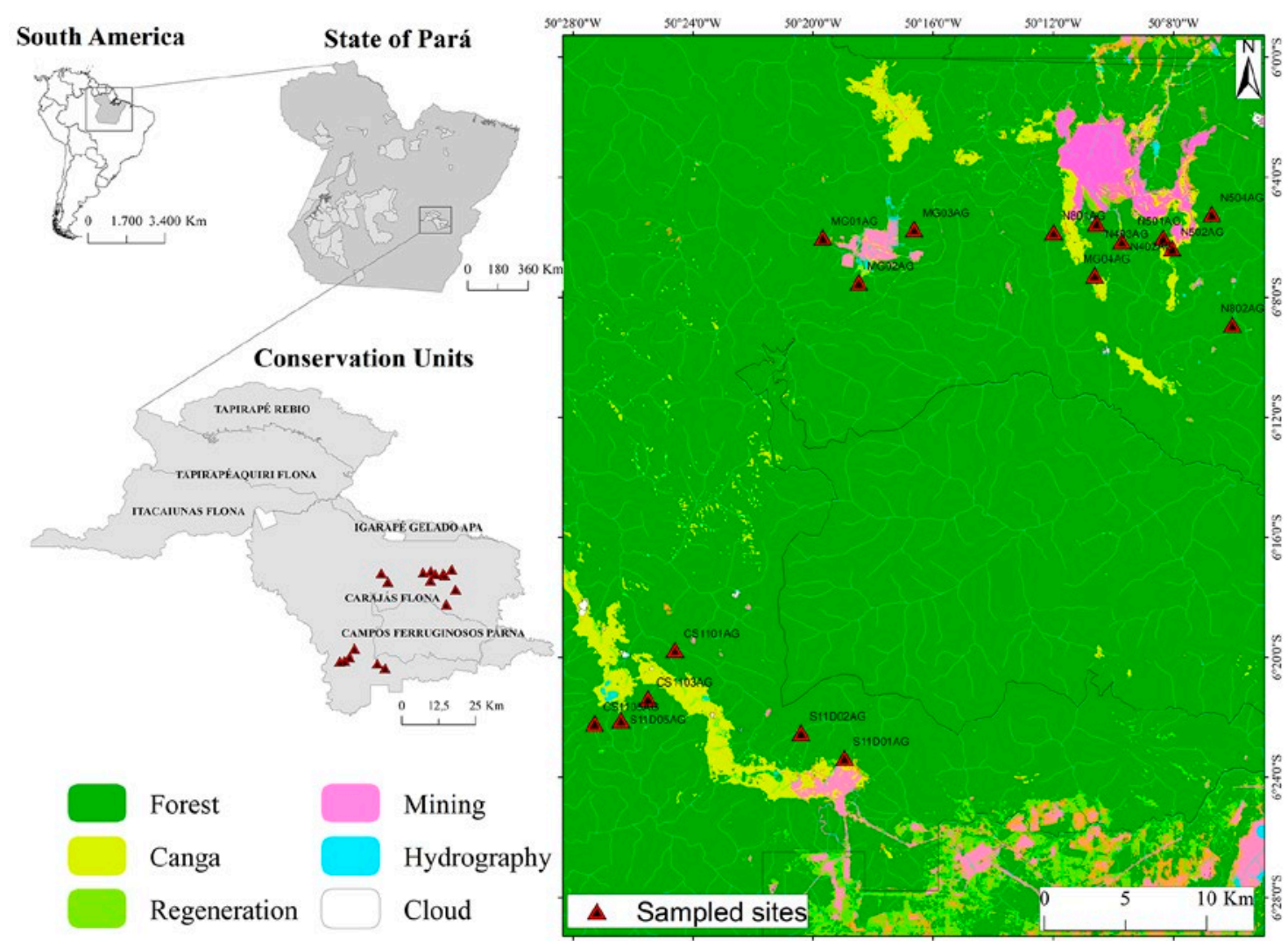

Figure 1. The 17 study streams sampled during the present study in the Carajás National Forest, Pará state, Brazil. The land use categories are shown in the legend.

The principal local hydrographic basin includes the Itacaiúnas and Parauapebas rivers, and covers an area of more than 11,500 km², which includes several first-order tributaries (Soares-Filho et al., 2014). The streams in the Itacaiúnas watershed have white (milky coffee-colored) water during the dry season, changing to yellow or red in the rainy season, when the sediment load increases (Ruivo \& Sales, 1989). Iron ore has been extracted within this area since 1970, which prompted the creation of the National Forest (IBAMA, 2003; Luiza-Andrade et al., 2020). As a result, the companies operating within this area must strictly respect Brazilian environmental legislation (the forest code, federal law 12,561/2012), which mandates the preservation of a 30-m buffer of riparian vegetation around all streams (ITV, 2017). 


\section{Biological sampling}

Samples were collected from 17 study streams in October and November 2015, which corresponds to the transition from the rainy to the dry season. The adults were collected between 10:00 am and 2:00 $\mathrm{pm}$, the period of the greatest incidence of sunlight, which is the ideal condition for the physiological requirements of the zygopterans (Corbet, 1999; Oliveira Júnior et al., 2015). Adult zygopterans were collected at each study stream within a standard $100 \mathrm{~m}$ stretch divided into 20 sections of $5 \mathrm{~m}$. Within each section, 10 transects were demarcated and named from A (downstream) to K (upstream). The insects were collected by fixed-area sweeping (Juen \& De Marco, 2011; Pinto et al., 2012; Monteiro Júnior et al., 2015) with an entomological net (diameter: $40 \mathrm{~cm}$; depth: $65 \mathrm{~cm}$ ) attached to a $90-\mathrm{cm}$ aluminum pole. Once collected, the specimens were stored in paper envelopes and immersed in acetone P.A. (pure for analysis) for 12 hours, following the protocol of Lencioni (2006). The specimens were identified at the Ecology and Conservation Laboratory of the Federal University of Pará in Belém using the relevant taxonomic keys (Garrison et al., 2006, 2010; Lencioni, 2005, 2006). The biological data were collected during the field campaigns of the integrated program for the monitoring of bioindicators in the Carajás National Forest, which aims to mitigate the impacts of the local mining operations on the region's biodiversity. Fieldwork at the Carajás Complex of the Vale S.A. mining corporation was authorized by the Brazilian Institute for the Environment and Renewable Natural Resources (IBAMA).

\section{Environmental variables}

The environmental dataset was composed of 12 variables (Supplementary Material; Tab. 2), which are all important drivers of zygopteran diversity, by determining the capacity of these insects to establish a viable population (Assis et al., 2004; Oliveira Júnior et al., 2015, Calvão et al., 2016; Oliveira-Junior \& Juen 2019). The HII (Nessimian et al., 2008) assesses the physical structure of the stream and its surroundings, and was calculated based on the values of the 12 environmental variables recorded at each stream. The scores for each variable in this protocol vary from 0 to 1 , with the values closer to 0 representing more impacted environments, and those closer to 1 representing more pristine habitats. A number of previous studies have applied this index to the analysis of the variables that influence the occurrence and distribution of odonates, and have provided important insights into the diversity of the zygopterans (Monteiro Júnior et al., 2014; Oliveira Júnior et al., 2015). In a recent meta-analysis, Brasil et al. (2020) obtained excellent results using the HII to evaluate the structure of communities of aquatic insects, and confirmed that this index is an effective parameter for the assessment of the environmental impacts that affect the aquatic biota. We also included the Impact Index (II) in our analysis, which was provided by the company that manages the study area. This index (II) measures the reduction of the habitat, considering the proximity of the mining activities to the sampling sites, with the extent of the impact on the fauna being expected to increase with increasing impact. On the other hand, the impact on the streams will be inversely related to the squared distance from the nearest mining zone (Espinoza et al., 2020). In the present study, we refer to the physical-chemical parameters as the limnological variables and the HII, II, and the distance to the nearest mining pit as the physical structure variables.

\section{Data analysis}

We applied a Variance Inflation Factor (VIF) to the limnological variables (James et al., 2014) to control for multicollinearity, and omitted the metrics with values that exceeded 5 . This left three variables $($ Dissolved Oxygen $=$ DO; environmental temperature $=$ ENVT; turbidity - turb $)$, which were included in the model, together with the HII and II (Supplementary Material; Tab. 2). A Principal Components Analysis (PCA) was applied to minimize the dimensionality of environmental data and describe the distribution of the sampling sites, for which the variables measured on different scales were standardized (Legendre \& Legendre 2012). The broken stick criterion was applied to the data to identify the most important axes derived from the variables, considering only the values that were at least as large as those predicted by the model (Jackson 1993). A Principal Coordinates Anal- 
ysis (PCoA) was applied, based on the Bray-Curtis dissimilarity index, to verify the variation in species composition among the study streams (Legendre \& Legendre 2012). For this, species abundance was $\log (\log [\mathrm{x}+1])$ transformed, and the first two axes were retained (Legendre \& Legendre 2012). To test our hypothesis, the first PCoA axis was used as a surrogate of species composition.

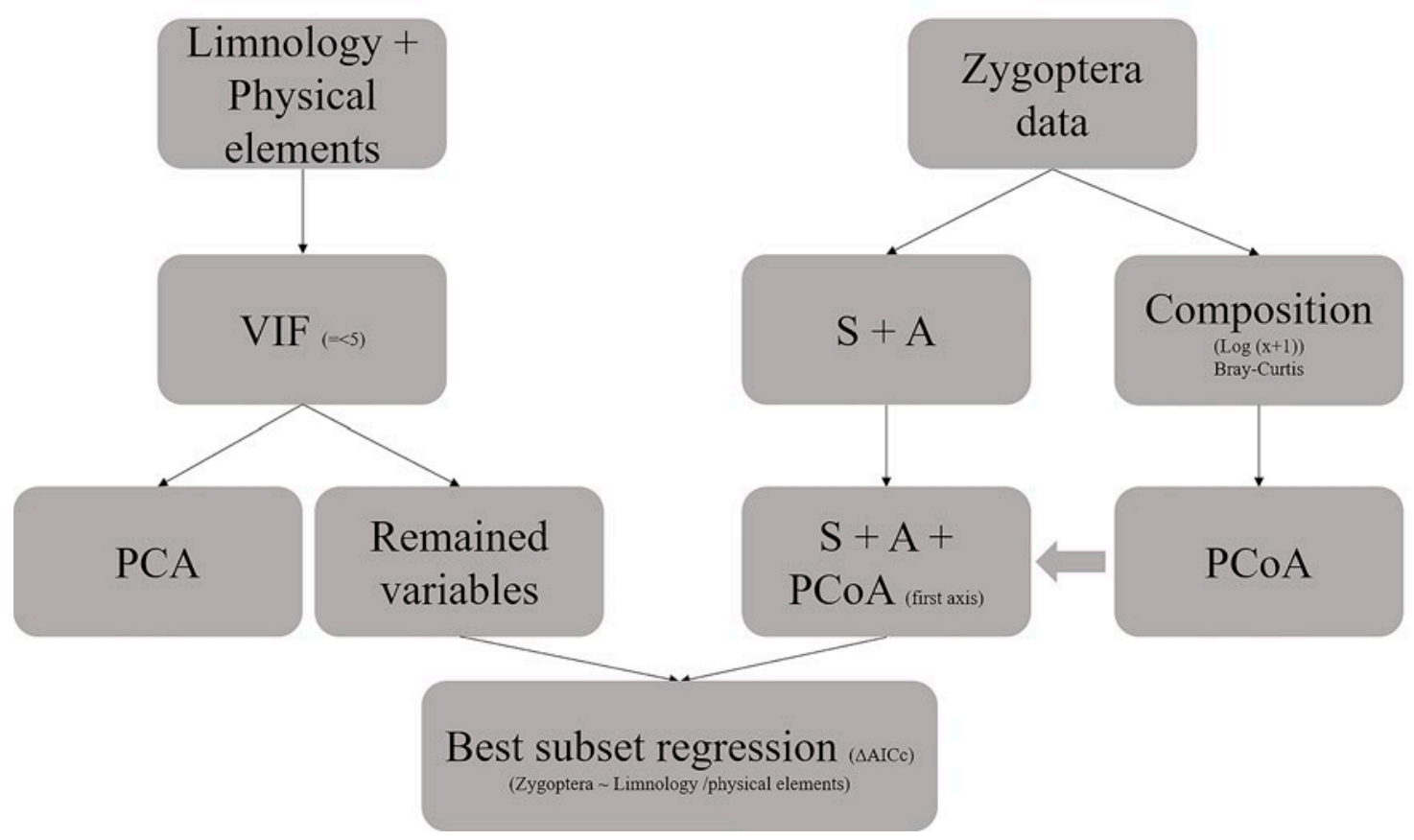

Figure 2. A summary of the statistical procedures used in the present study. $\triangle A I C c=$ difference in the Akaike Information Criterion in comparison with the lowest AICc value; HII= Habitat Integrity Index; PCA = Principal Components Analysis; PCoA = Principal Coordinates Analysis; N = zygopteran abundance; $\mathbf{S}=$ zygopteran species richness.

We ran a Multiple Linear Regression (MLR) to assess the responses of the zygopteran diversity metrics (species richness, composition, and abundance) to the predictor variables (limnological parameters, physical structure (HII and II), and the distance from the streams to the mining pits) using best subsets regression (Harrell 2001). This procedure involves compiling the regression models of all the possible combinations of predictor variables and selecting the best model, which meets the pre-defined criteria (Lynch et al., 2018). The models were ranked using the Akaike Information Criteria for small sample size (AICc), to identify the optimum models (Burnham \& Anderson 2002). The best model from each dataset had the lowest AICc value, while models with AICc values of less than 2 $(\triangle \mathrm{AICc}<2)$ were also considered to be good predictors of diversity. The PCA and PCoA were run in the R environment (R Core Team 2017), using the 'vegan', 'MASS', and 'ggplot2' packages (Wickham 2016), and the best subsets regression procedure was run in Systat 13. The analytical procedures are summarized in Figure 2.

\section{Results}

\section{General description of the zygopteran assemblages}

A total of 343 zygopteran adults were collected during the present study, representing four families (Coenagrionidae, Polythoridae, Calopterygidae, and Megapodagrionidae), and 19 species (Supplementary Material; Tab. 1). The most abundant species was Chalcopteryx rutilans Rambur 1842, with 
104 individuals. The second most abundant species was Argia tinctipennis Selys 1865, with 69 individuals, followed by Hetaerina indeprensa Garrison 1990 with 35 individuals, and Mnesarete aenea Selys 1853 with 23 .

\section{General description of abiotic variables and species composition}

The PCoA explained $46.3 \%$ of the total variance on its first two axes, with $28.53 \%$ in the first axis, and $17.77 \%$ in the second (Figure $3 \mathrm{~A}$ ). However, the analysis did not the existence of a defined distribution pattern in the species composition, which varied randomly.

The broken stick model retained both of the first two PCA axes, which together explained $69.58 \%$ of the total variation, with the sites with the highest II scores appearing the lower left corner of the ordination, and some of the sites with higher HII scores in the upper left corner (Table 1; Figure 3B). Dissolved oxygen was the variable that contributed most to the first axis (0.747), while turbidity $(-0.919)$ and the II $(-0.561)$ had the greatest negative influence on the first axis (Figure 3B). The HII was the most important variable on the second axis, with a positive score of 0.899 (Figure 3B).
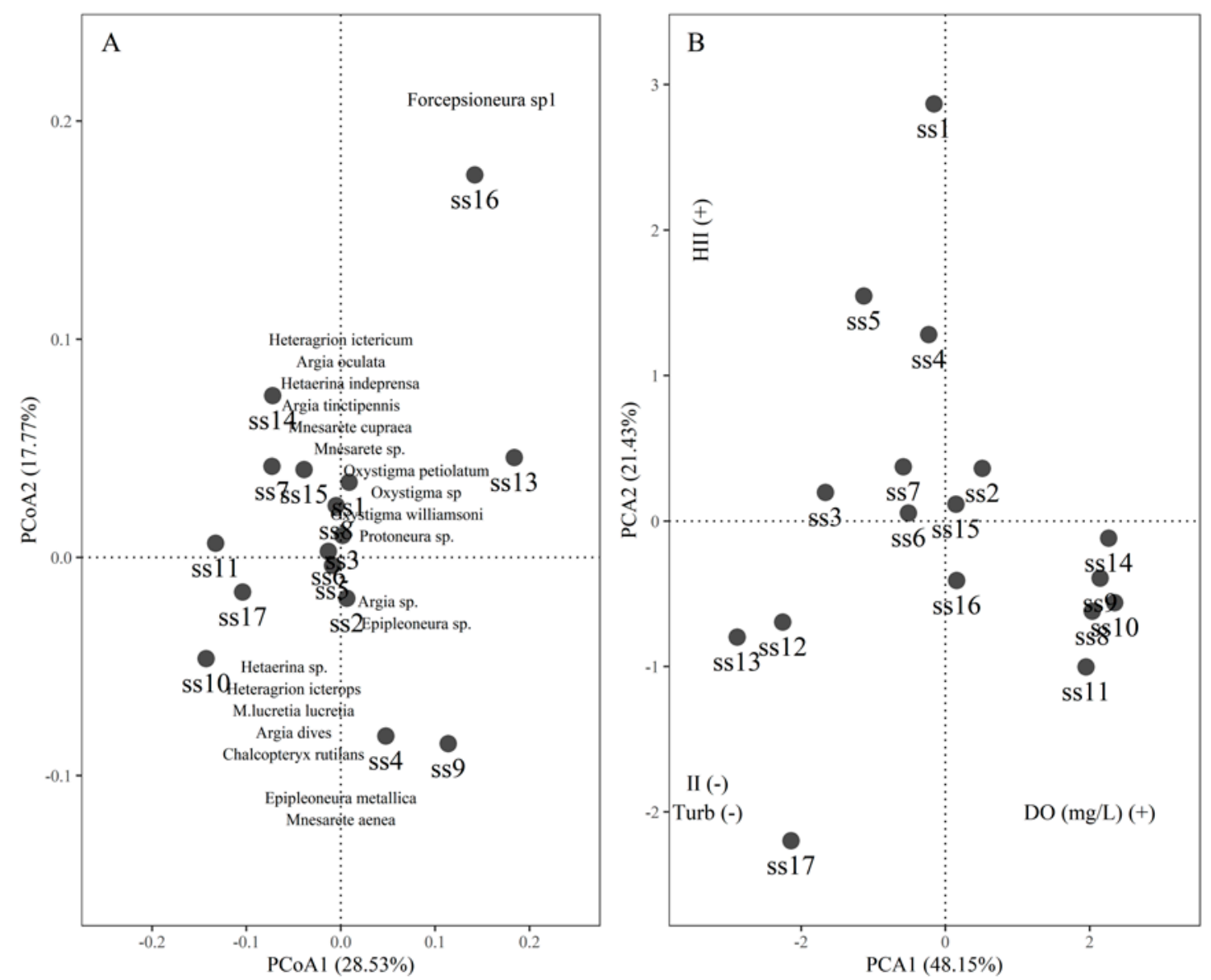

Figure 3. Ordination of the abiotic and biotic data - A: Principal Coordinates Analysis (PCoA) applied to the data on the zygopteran species composition; B: Principal Components Analysis (PCA) applied on the abiotic data. Turb = turbidity; DO = dissolved oxygen. $\mathrm{HII}=$ habitat integrity index; II = impact index. 
Table 1. Mean, standard deviation (SD), and maximum/minimum values of the five variables included in the PCA (Principal Component Analysis) of environmental factors. The values were obtained at the study streams in the Carajás National Forest, Pará state, Brazil.

\begin{tabular}{|l|l|l|l|l|}
\hline Variables & Mean & SD & Maximum & Minimum \\
\hline Dissolved Oxygen (mg/L) & 7.64 & 1.27 & 8.60 & 3.48 \\
\hline $\begin{array}{l}\text { Environmental Temperature, } \\
\text { ENVT }\left({ }^{\circ} \mathbf{C}\right)\end{array}$ & 27.48 & 6.72 & 30.70 & 25.00 \\
\hline Turbidity (NTU) & 5.47 & 4.24 & 13.90 & 0.67 \\
\hline Habitat Integrity Index (HII) & 0.87 & 0.11 & 0.56 & 0.97 \\
\hline Impact Index (II) & 10.81 & 15.86 & 60.04 & 0.13 \\
\hline
\end{tabular}

Table 2. Multiple linear regressions (best subsets) of the zygopteran diversity metrics and their relationship with the environmental and physical predictors at the study streams in the Carajás National Forest, Pará, Brazil. AIC = Akaike Information Criterion; AIC $=$ Akaike Information Criterion corrected for small samples; $\triangle \mathrm{AICC}=\mathrm{AICc}$ ranking based on the minimum value; $\mathrm{DO}=$ Dissolved Oxygen; ENVT $=$ environmental temperature ; HII = Habitat Integrity Index; PCoA1 = first axis of the Principal Coordinates Analysis; TURB = turbidity; $\beta$ = beta coefficient.

\begin{tabular}{|c|c|c|c|c|c|}
\hline Selected model & AIC & AICc & $\triangle \mathrm{AICc}$ & Adjusted $\mathbf{R}^{2}$ & $\beta$ \\
\hline \multicolumn{6}{|l|}{ Species richness } \\
\hline DO + ENVT & 77.163 & 80.496 & $\mathbf{0}$ & 0.231 & $-0.834 ; 0.592$ \\
\hline $\mathrm{DO}+\mathrm{TURB}$ & 78.131 & 81.464 & 0.968 & 0.186 & $-1.191 ;-0.279$ \\
\hline HII & 79.622 & 81.468 & 0.972 & 0.067 & 7.195 \\
\hline ENVT & 79.694 & 81.540 & 1.044 & 0.063 & 0.435 \\
\hline \multicolumn{6}{|l|}{ Abundance } \\
\hline HII & 131.238 & 135.084 & $\mathbf{0}$ & 0.099 & 39.42 \\
\hline DISTANCE & 133.980 & 135.827 & 0.743 & 0.058 & 9.389 \\
\hline DISTANCE + TURB & 132.750 & 136.083 & 0.999 & 0.166 & $0.002 ; 1,238$ \\
\hline ENVT + TURB & 133.025 & 136.359 & 1.275 & 0.152 & $4.409 ; 1.701$ \\
\hline \multicolumn{6}{|l|}{ Composition (PCoA1) } \\
\hline DO & 4.078 & 5.924 & $\mathbf{0}$ & 0.037 & -0.063 \\
\hline DISTANCE & 4.704 & 6.550 & 0.626 & 0.001 & $>0.001$ \\
\hline $\mathrm{DO}+\mathrm{TURB}$ & 4.374 & 7.707 & 1.783 & 0.066 & $-0.108 ;-0.021$ \\
\hline DO +DISTANCE & 4.430 & 7.763 & 1.839 & 0.063 & $-0.069 ;>0.001$ \\
\hline
\end{tabular}




\section{Effects of environmental variables and physical structuring on the Zygoptera}

The best subsets regression indicated that both types of environmental parameter influence all the zygopteran diversity metrics in some ways, although in most cases, the relationship was relatively discreet (Table 2). However, our hypothesis was supported, in part, by the results, given that the HII influenced only zygopteran abundance when analyzed on its own, while the II did not influence the diversity or abundance of the zygopterans (Table 2). Species richness was best explained by the model that combined DO and environmental temperature $\left(\mathrm{R}^{2} \mathrm{adj}=0.231\right)$. However, the model that included only the HII best explained the abundance of individuals, albeit with a greatly reduced explanation value $\left(\mathrm{R}^{2} \mathrm{adj}=0.099\right)$. The distance from the stream to the near mining pit was also prevalent in the zygopteran abundance models, although once again, with only low values (Table 2). The best model selected to explain the zygopteran species composition was formed exclusively by DO, but once again, with a greatly-reduced value of explanation $\left(\mathrm{R}^{2}\right.$ adj $\left.=0.037\right)$, with a similar pattern being observed in the distance from the pit (Table 2). It is important to note that turbidity was the variable selected most frequently by the $\triangle \mathrm{AICc}(<2)$, playing a role in the models of all the diversity metrics, followed by all the other variables, except the II (Table 2).

\section{Discussion}

The hypothesis tested in the present study was partially corroborated, by showing that the HII was the principal parameter of physical structure that drove zygopteran abundance. Although the limnological features had a considerable influence on all the zygopteran diversity metrics, and were the principal drivers of species composition and abundance, the low explanatory values do not uphold our hypothesis. The HII values, which represent the physical structure of the stream, also varied discreetly, from 0.57 to 0.99 , which indicates that most of the study sites had a relatively high level of habitat integrity, with good vegetation cover and stable environmental conditions. This may have accounted for the broadly similar patterns found among sites, given that the relative homogeneity of the riparian vegetation is an important factor in zygopteran biology (Calvão et al., 2016; Carvalho et al., 2018).

The limnological parameters provided important insights in the present study, given their fundamental influence on the zygopteran communities (Mendes et al., 2018). Turbidity can influence the selection of oviposition sites by the female, for example (e.g. Carvalho \& Nessimian, 1999), given that they typically prefer more transparent water. The influence of the physical-chemical parameters of the water on the occurrence of adult zygopterans should be interpreted with caution, however, given that the adult and nymph stages are closely related (Valente-Neto et al., 2015; Mendes et al., 2017; Iwai et al., 2017), which implies that the factors affecting one stage may affect the other by default (Brito et al., 2020). As the present study focused on the adults, then, a more integrated approach would be needed to provide more conclusive insights into these patterns. Dissolved oxygen was the principal variable influencing zygopteran species richness and composition, with negative beta coefficient values indicating a certain loss of integrity (Calvão et al., 2018). This outcome is quite interesting because, even though the HII was not retained as the principal variable in all the models, the DO does show that changes in water composition are occurring and may influence the odonate larval stages (Mendes et al., 2018). We cannot make further inferences, however, given that we did not evaluate this life stage in the present study.

The HII evaluates the completeness and integrity of the riparian forest in the context of the potential impact of human activities (Nessimian et al., 2008). The integrity of this habitat is fundamental to the maintenance of stable temperatures and the filtering of the sediment input, as well as providing a dispersal corridor for many stream-dwelling species (Oliveira Júnior et al., 2015; Calvão et al., 2018; Carvalho et al., 2018). In the present study, in fact, only one stream (ss1) had an HII lower than 0.80, 
even though some sites were located in the vicinity of mining zones. This undoubtedly reflects the systematic application of federal law 12,561/2012, which mandates the preservation of the riparian zone by companies extracting natural resources, in order to preserve ecological networks and protect water resources. These protective measures ensure the conservation of the riparian zone, an important factor influencing the diversity of zygopteran species (Monteiro-Júnior et al., 2015; Nagy et al., 2019), given that these organisms have highly specific physiological requirements, which demand not only vegetation cover, but also environmental stability.

The present study focused only on zygopteran ectotherms, which are unable to regulate their body temperature (Oliveira Júnior et al., 2015), which further reinforces the importance of the riparian influence zone for the occurrence of species. In addition, the distance from each stream to the the nearest mining pit was a factor in both zygopteran abundance and species composition, albeit in a secondary role, which indicates that this impact is not extensive enough to impede the dispersal of the damselflies across the environmental gradient. Despite being much smaller than the dragonflies (suborder Anisoptera), the damselflies appear to be capable of traversing the habitat gradient of the study area to reach other suitable sites. It is important to note here that the study area is located within a large broad conservation unit, and that even the streams in closet proximity to mining pits have intact riparian forest, which ensures the connectivity among and guarantees species dispersal. Alternatively, it is possible that the stability of the physical structure of the habitats ensures the homogeneity of the chemical composition of the water, its dissolved oxygen concentration, and turbidity, which is essential for the zygopteran adults (Raebel et al., 2012; Calvão et al., 2016; Mendes et al., 2018).

Brasil et al. (2020) found that the HII is an effective predictor of the composition of aquatic insect communities in Brazilian stream systems. This study highlighted the correlation between environmental variables, such as dissolved oxygen and turbidity, and the HII, which quantifies the physical structure of the stream (Nessimian et al., 2008). Higher HII scores indicate a greater degree of integrity, that is, environmental stability. Habitat integrity thus has a fundamental influence on the environmental dynamics of these systems, including the chemical composition of the water and physical conditions such as air temperature, which are all crucial for zygopterans. The well-preserved riparian forest found throughout the area of the present study area may account for the abundance of some species, such as $C$. rutilans, whose females require specific breeding sites, which are only found in well-preserved environments (Resende \& De Marco Júnior 2010). The C. rutilans females lay their eggs on fallen tree trunks and other structures derived from the riparian forest (Resende 2010), and their dependence on these structures would account for their marked association with more pristine environments (Resende \& De Marco Júnior 2010; Calvão et al., 2016). As this species contributed a large proportion (33\%) of the individuals collected in the present study, a greater distance from the zone of impact may have been necessary to guarantee the occurrence of this species, given that this distance was related to damselfly abundance.

In the present study, both limnological factors (physical-chemical properties of the water) and physical structuring (HII and mining), had a significant influence on zygopteran diversity. That is, both factors mold the establishment, reproduction, and survival of these organisms. Environmental stability is critical to the zygopterans, which are small insects with slender bodies. As for the habitat integrity index, the environmental features varied only discreetly among sites, indicating a high degree of stability, with low adjusted $\mathrm{R}^{2}$ values. One other important factor here was the relatively reduced spatial scale of the study area, which likely reinforced the similarities among the sites. One way to increase the sensitivity of the analytical approach adopted here would be to compare a much broader selection of sites that encompass a greater degree of variation in both the HII and the environmental parameters. Overall, them the physical habitat appears to be the principal factor driving the structuring of zygopteran diversity, which reinforces the need to consider local factors for the planning of conservation measures for aquatic ecosystems in the Amazon region. 


\section{Acknowledgements}

We would like to thank IBAMA and the Chico Mendes Institute for Biodiversity Conservation (IC$\mathrm{MBio}$ ), the federal organs responsible for the environmental licensing of the Carajás mining enterprise and the environmental monitoring programs, in addition to the authorization of the present study. We are extremely grateful to Gilberto Nicácio, Fernando G. Carvalho, Yulie S. Feitosa, Thiago P. Mendes, Leandro Brasil, and Ana L. Andrade for their help with collection of data in the field. We would also like to thank Amplo Engenharia e Gestão de Projeto for logistic support, and we are grateful to the Vale Company for allowing us to collect data within its area of operation in the Carajás region. We are indebted to Frederico A. Lencioni, Angelo Pinto, and Lenize B. Calvão for the identification of the zygopteran taxa, without whose help this study would not have been possible. We are grateful to CNPq Brazil (Conselho Nacional de Desenvolvimento Científico e Tecnológico) for a doctoral scholarship to JSB (process 141113/2020-0) and for research productivity scholarships to LJ (process 304710/2019-9). EJC would also like to thank the Biodiversity Research Consortium BrazilNorway (BRC) for a scholarship (record number process 3804-1). We would also like to thank MSc. Naiara Rayol for producing the map, Stephen Ferrari for revising the English text, and three anonymous reviewers for their suggestions on a previous version of the manuscript.

\section{Funding}

We are grateful to the Conselho Nacional de Desenvolvimento Científico e Tecnológico (CNPq) for supporting LJ's research through productivity grants, a scientific initiation scholarship to JSB (Process 307597/2016-4), and a scholarship to LBC (Process 154761/2018-4).

\section{Supplementary Data}

Supplementary data for this article can be accessed here.

\section{References}

Ab'Saber, A.N. (1986). Geomorfologia da Região de Carajás. In J. M. G. Almeida (Ed.), Carajás. Desafio político, ecologia e desenvolvimento (pp. 88-124). Brasiliense.

Assis, J.C.F., Carvalho, A.L., \& Nessimian, J.G. (2004). Composição e preferência por micro-habitat de larvas de Odonata (Insecta) em um trecho de baixada do Rio Ubatiba, Maricá-RJ, Brasil. Revista Brasileira de Entomologia 48(2), 273-282. https://doi.org/10.1590/S0085-56262004000200017.

Astudillo, M.R., Novelo-Gutiérrez, R., Vásquez, G., García-Franco, J.G., \& Ramírez, A. (2016). Relationships between land cover, riparian vegetation, stream characteristics, and aquatic insects in cloud forest streams, Mexico. Hydrobiologia 768(1), 167-181. https://doi.org/10.1007/s10750015-2545-1.

Brasil, L.S., D’arc Batista, J., Giehl, N.F.S., Valadão, M.B.X., dos Santos, J.O., \& Dias-Silva, K. (2014a). Environmental integrity and damselfly species composition in Amazonian streams at the "arc of deforestation". Acta Limnologica Brasiliensia 26 (3), 278-287. https://doi.org/10.1590/ S2179-975X2014000300007.

Brasil, L.S., Giehl, N.F.S., Almeida, S.M., Valadão, M.B.X., dos Santos, J.O., Pinto, N.S., \& D’arc Batista, J. (2014b). Does the damming of streams in the southern Amazon basin affect dragonfly and damselfly assemblages (Odonata: Insecta)? A preliminary study. International Journal of Odonatology 17(4), 187-197. https://doi.org/10.1080/13887890.2014.963712. 
Brasil, L.S., Oliveira Júnior, J.M.B., Calvão, L.B., Carvalho, F.G., Monteiro Júnior, C.S., Dias-Silva, K., \& Juen, L. (2018). Spatial, biogeographic and environmental predictors of diversity in Amazonian Zygoptera. Insect Conservation and Diversity 11(2), 174-184. https://doi.org/10.1111/ icad.12262.

Brasil, L. S., Lima, E. L., Spigoloni, Z. A., Ribeiro-Brasil, D. R. G., \& Juen, L. (2020). The habitat integrity index and the aquatic insect communities in tropical streams: A meta-analysis. Ecological Indicators. https://doi.org/10.1016/j.ecolind.2020.106495.

Brito, J.S., Michelan, T.S., \& Juen, L. (2020) Aquatic macrophytes are important substrates for Libellulidae (Odonata) larvae and adults. Limnology. https://doi.org/10.1007/s10201-02000643-x.

Burnham, K.P. \& Anderson, D.R. (2002). Model Selection and Multimodel Inference: A Practical Information-Theoretic Approach. Springer-Verlag.

Callisto, M., Esteves, F. A., Gonçalves, J. F., \& Leal, J. J. F. (1998). Impact of bauxite tailings on the distribution of benthic macrofauna in a small river ('igarapé') in central Amazonia, Brazil. Journal of the Kansas Entomological Society 71(4), 447-455.

Callisto, M., Moretti, M., \& Goulart, M. (2001). Macroinvertebrados Bentônicos como Ferramenta para Avaliar a Saúde de Riachos. Biologia 6(1), 71-82. https://doi.org/10.1080/11358129809487577.

Calvão, L.B., Nogueira, D.S., Montag, L.F.A., Lopes, M.A., \& Juen, L. (2016). Are Odonata communities impacted by conventional or reduced impact logging? Forest Ecology and Management 382, 143-150. https://doi.org/10.1016/j.foreco.2016.10.013.

Calvão, L. B., Juen, L., Oliveira Junior, J. M. B., Batista, J. D., \& De Marco Júnior, P. (2018). Land uses modifies Odonata diversity in streams of the Brazilian Cerrado. Journal of Insect Conservation 22, 675-685. https://doi.org/10.1007/s10841-018-0093-5.

Carvalho, A.L., \& Nessimian, J.L. (1997). Odonata do Estado do Rio de Janeiro, Brasil: hábitats e hábitos das larvas. In J. L. Nessimian \& A. L. Carvalho (Eds.) Ecologia de insetos aquáticos (pp. 3-28). Series Oecologia Brasiliensis. https://doi.org/10.4257/oeco.1998.0501.01.

Carvalho, F.G., Pinto, N.S., Oliveira Júnior, J.M.B., \& Juen, L. (2013) Effects of marginal vegetation removal on Odonata communities Efeitos da retirada da vegetação marginal sobre a comunidade de Odonata. Acta Limnologica Brasiliensia. https://doi.org/10.1590/S2179-975X2013005000013.

Carvalho, F. G., Oliveira Roque, F., Barbosa, L., Montag, L. F. A., \& Juen, L. (2018). Oil palm plantation is not suitable environment for most forest specialist species of Odonata in Amazonia. Animal Conservation. https://doi.org/10.1111/acv.12427.

Corbet, P.S. (1999). Dragonflies: Behaviour and Ecology of Odonata. Comstock Publisher Association.

Corbet, P. S., \& May, M.L. (2008). Fliers and perchers among Odonata: dichotomy or multidimensional continuum? A provisional reappraisal. International Journal of Odonatology 11, 155 - 171.

Cunha, E.J., Montag, L.F.A., \& Juen, L. (2015). Oil palm crops effects on environmental integrity of Amazonian streams and Heteropteran (Hemiptera) species diversity. Ecological Indicators 52, 422-429. https://doi.org/10.1016/j.ecolind.2014.12.024.

Dolný, A., Harabiš, F., \& Mižičová, H. (2014). Home range, movement, and distribution patterns of the threatened dragonfly Sympetrum depressiusculum (Odonata: Libellulidae): A thousand times greater territory to protect? PLoS ONE 9(7), 1-10. https://doi.org/10.1371/journal.pone.0100408.

Enríquez-Espinosa, A. C. E., Shimano, Y., Rolim, S., Maioli, L., Juen, L., \& Dunck, B. (2020). Mining effects and lower turnover of Ephemeroptera (Insecta) in Brazilian streams of Eastern Amazon. Journal of Insect Conservation 24: 1061 - 1072. https://doi.org/10.1007/s10841-020-00275-7.

Federal Law 12.727, 17 October 2012. Available at www.planalto.gov.br/ccivil_03/_Ato20112014/2012/Lei/L12727.htm.

Fearnside, P.M. (2006). Dams in the Amazon: Belo Monte and Brazil's hydroelectric development of the Xingu River Basin. Environmental Management 38, 16-27. https://doi.org/10.1007/s00267005-0113-6.

Garrison, R.W., von Ellenrieder, N., \& Louton, J.A. (2006). Dragonfly genera of the new world: an illustrated and annotated key to the Anisoptera. The John Hopkins University Press.

Garrison, R.W., Ellenrieder, N.V., \& Louton, J.A. (2010). Dragonfly genera of the newworld: An illustrated and annotated key to the Zygoptera. The Johns Hopkins University Press. 
Harrell, F. (2001). Regression modeling strategies. Springer-Verlag New York. https://doi.org/10.1007/978$1-4757-3462-1$

Heino, J., Parviainen, J., Paavola, R., Jehle, M., Louhi, P., \& Muotka, T. (2005). Characterizing macroinvertebrate assemblage structure in relation to stream size and tributary position. Hydrobiologia 539, 121-130. https://doi.org/10.1007/s10750-004-3914-3.

Heino, J. (2013). Does dispersal ability affect the relative importance of environmental control and spatial structuring of littoral macroinvertebrate communities? Oecologia 171 (4), 971-980. https://doi.org/10.1007/s00442-012-2451-4.

IBAMA (2003) Instituto Brasileiro do Meio Ambiente e dos Recursos Naturais. PLANO DE MANEJO PARA USO MÚLTIPLO DA FLORESTA NACIONAL DE CARAJÁS. Brasília.

ITV (2017). Paisagens e plantas de Carajás - Landscapes and plants of Carajás. Instituto Tecnológico Vale.

Iwai, N., Akasaka, M., Kadoya, T., Ishida, S., Aoki, T., Higuchi, S., \& Takamura, N. (2017). Examination of the link between life stages uncovered the mechanisms by which habitat characteristics affect odonates. Ecosphere. https://doi.org/e01930.10.1002/ecs2.1930.

Jackson, D. (1993). Stopping Rules in Principal Components Analysis: A Comparison of Heuristical and Statistical Approaches. Ecology 74(8), 2204-2214. https://doi.org/10.2307/1939574.

James, G. Witten, D. Hastie, T. \& Tibshirani, R. (2014) An Introduction to Statistical Learning: With Applications in R. Springer Publishing Company Incorporated. https://doi.org/10.1007/978-14614-7138-7.

Juen, L., \& De Marco Júnior, P. (2011). Odonate biodiversity in terra-firme forest streamlets in Central Amazonia: on the relative effects of neutral and niche drivers at small geographical extents. Insect Conservation Diversity 4, 1-10. https://doi.org/10.1111/j.1752-4598.2010.00130.x.

Kovalenko, K.E., Thomaz, S.M., \& Warfe, D.M. (2012). Habitat complexity: Approaches and future directions. Hydrobiologia 685(1), 1-17. https://doi.org/10.1007/s10750-011-0974-z.

Lampert, W., \& Sommer, U. (2007). Limnoecology: The ecology of lakes and streams. Oxford University Press.

Landeiro, V.L., Magnusson, W.E., Melo, A.S., Espírito-Santo, H.M.V., \& Bini, L.M. (2011). Spatial eigenfunction analyses in stream networks: Do watercourse and overland distances produce different results? Freshwater Biology 56(6), 1184-1192. https://doi.org/10.1111/j.1523-1739.2007.00870.x.

Landeiro, V.L., Bini, L.M., Melo, A.S., Pes, A.M.O., \& Magnusson, W.E. (2012). The roles of dispersal limitation and environmental conditions in controlling caddisfly (Trichoptera) assemblages. Freshwater Biology 57(8), 1554-1564. https://doi.org/10.1111/j.1365-2427.2012.02816.x.

Legendre, P., \& Legendre, L. (2012). Numerical ecology. Amsterdam: Elsevier.

Lencioni, F.A.A. (2005). Damselflies of Brazil, an Illustrated Identification Guide: I- The Non-Coenagrionidae Families. All Print Editora.

Lencioni, F.A.A. (2006). Damselflies of Brazil, an Illustrated Identification Guide: II -Coenagrionidae Families. All Print Editora.

Luiza-Andrade, A., Brasil, L. S., Torres, N. R., Brito, J., Silva, R. R., Maioli, L. U., Barbirato, M. F., Rolim, S. G., \& Juen, L. (2020). Effects of local environmental and landscape variables on the taxonomic and trophic composition of aquatic insects in a rare forest formation of the Brazilian Amazon. Neotropical Entomology 49, 821-831. https://doi.org/10.1007/s13744-02000814-6.

Lynch, D. T., Leasure, D. R., \& Magoulick, D. D. (2018) The influence of drought on flow-ecology relationships in Ozark highland streams. Freshwater Biology 63: 946-968. https://doi.org/10.1111/ fwb.13089

MacArthur, R.H., \& MacArthur, J.W. (1961). On Bird Species Diversity. Ecological Society of America 42(3), 594-598. https://doi.org/10.2307/1932254.

Mafuwe, K., \& Moyo, S. (2020). Dragonfly (Odonata) community structure in eastern highlands biodiversity hotspots of Zimbabwe: potential threats of land use changes on freshwater invertebrates. International Journal of Odonatology. https://doi.org/10.1080/13887890.2020.1768156.

Maloney, K.O., \& Weller, D.E. (2011). Anthropogenic disturbance and streams: land use and land-use change affect stream ecosystems via multiple pathways. Freshwater Biology 56, 611-626. https:// doi.org/10.1111/j.1365-2427.2010.02522.x. 
Mendes, T. P., Oliveira-Junior, J. M. B., Cabette, H. S. R., Batista, J. D., \& Juen, L. (2017). Congruence and biomonitoring of aquatic ecosystems: Are Odonate larvae or adults the most effective for the evaluation of impacts? Neotropical Entomology. https://doi.org/10.1007/s13744-017-0503-5.

Mendes, T.P., Luiza-Andrade, A., Cabette, H.S.R., \& Juen, L. (2018). How Does Environmental Variation Affect the Distribution of Dragonfly Larvae (Odonata) in the Amazon-Cerrado Transition Zone in Central Brazil? Neotropical Entomology 47(1), 37-45. https://doi.org/10.1007/s13744-0170506-2.

Monteiro, M. (2005). Meio século de mineração industrial na Amazônia e suas implicações para o desenvolvimento regional. Estudos Avançados 19, 187-207. https://doi.org/10.1590/S010340142005000100012

Monteiro-Júnior, C. S., Juen, L., \& Hamada, N. (2015) Analysis of urban impacts on aquatic habitats in the central Amazon basin: Adult odonates as bioindicators of environmental quality. Ecological Indicators 48, 303-311. https://doi.org/10.1016/j.ecolind.2014.08.021.

Moraes, B.C., Costa, J.M.N., Costa, A.C.L., \& Costa, M.H. (2005). Variação espacial e temporal da precipitação no estado do Pará. Acta Amazonica 35, 207-214. https://doi.org/10.1590/S004459672005000200010

Nagy, H. B., László, Z., Szabó, F., Szöcs, L., Dévai, G., \& Tóthmérész, B. (2019). Landscape-scale terrestrial factors are also vital in shaping Odonata assemblages of watercourse. Scientific Reports. https://doi.org/10.1038/s41598-019-54628-7.

Nessimian, J.L., Venticinque, E.M., Zuanon, J., De Marco Júnior, P., Gordo, M., Fidelis, L., D’arc Batista, J., \& Juen, L. (2008). Land use, habitat integrity, and aquatic insect assemblages in Central Amazonianstreams.Hydrobiologia614(1),117-131.https://doi.org/10.1111/j.1523-1739.2007.00870.x

Oliveira Júnior, J.M., \& Juen, L. (2019). The Zygoptera / Anisoptera ratio (Insecta: Odonata): a new tool for habitat alterations assessment in Amazonian stream. Neotropical Entomology 48: 552-560. https://doi.org/10.1007/s13744-019-00672-x.

Oliveira Júnior, J.M., Shimano, Y., Gardner, T.A., Hughes, R.M., De Marco Júnior, P., \& Juen, L. (2015). Neotropical dragonflies (Insecta: Odonata) as indicators of ecological condition of small streams in the eastern Amazon. Austral Ecology 40(6), 733-744. https://doi.org/10.1111/aec.12242.

Peel, M.C., Finlayson, B.L., \& McMahon, T.A. (2007). Updated world map of the Koppen-Geiger climate classification. Hydrologycal Earth Systems Science Discussion 4, 439-473.

Pinto, N.S., Juen, L., Cabette, H.S.R., \& De Marco Júnior, P. (2012). Fluctuating Asymmetry and Wing Size of Argia tinctipennis Selys (Zygoptera: Coenagrionidae) in Relation to Riparian Forest Preservation Status. Neotropical Entomology 41(3), 178-185. https://doi.org/10.1007/s13744-012-0029-9.

Raebel, E. M., Merckx, T., Feber, R. E., Riordan, P., Thompson, D.J., \& Macdonald, D. W. (2012) Multiscale effects farmland management on dragonfly and damselfly assemblages of farmland ponds. Agriculture, Ecosystems and Environment 161, 80-87. https://doi.org/10.1016/j.agee.2012.07.015.

R Core Team. (2017). R: A language and environment for Statistical computing. R Foundation for Statistical Computing.

Resende, D.C., \& De Marco Júnior, P. (2010). First description of reproductive behavior of the Amazonian damselfly Chalcopteryx rutilans (Rambur) (Odonata, Polythoridae). Revista Brasileira de Entomologia 54(3), 436-440. https://doi.org/10.1590/S0085-56262010000300013.

Resende, D.C. (2010). Residence advantage in heterospecific territorial disputes of Erythrodiplax Brauer species (Odonata, Libellulidae). Revista Brasileira de Entomologia 54, 110-114. https:// doi.org/10.1590/S0085-56262010000100014.

Ruivo, M.L.P., \& Sales, M.E.C. (1989). Monitoramento da qualidade da água na área do Projeto de Ferro Carajás - Subsídio para estudo ambiental. Boletím do Museu Paraense Emilio Goeldi.

Siqueira, T., Lacerda, C. G. L. T., \& Saito, V. S. (2015) How does the landscape modification induce biological homogenization in tropical stream communities? Biotropica 47(4), 509-516. https:// doi.org/10.1111/btp.12224.

Soares-filho, B., Rajão, R., Macedo, M., Carneiro, A., Costa, W., Coe, M., Rodrigues, H., \& Alencar, A. (2014). Cracking Brazil's Forest Code. Science 344(4), 363-364. https://doi.org/10.1126/science. 1246663

Thomaz, S.M., \& Cunha, E.R. (2010). The role of macrophytes in habitat structuring in aquatic ecosystems: methods of measurement, causes and consequences on animal assemblages' composition and biodiversity. Acta Limnologica Brasiliensia 22(2), 218-236. https://doi.org/10.4322/ actalb.02202011. 
Tonkin, J.D., Altermatt, F., Finn, D.S., Heino, J., Olden, J.D., Pauls, S.U., \& Lytle, D.A. (2017). The role of dispersal in river network metacommunities: Patterns, processes, and pathways. Freshwater Biology 63(1), 141-163. https://doi.org/10.1111/fwb.13037.

Valente-Neto, F., De Oliveira Roque, F., Rodrigues, M.E., Juen, L., \& Swan, C.M. (2015). Toward a practical use of neotropical odonates as bioindicators: Testing congruence across taxonomic resolution and life stages. Ecological Indicators 61, 952-959. https://doi.org/10.1016/j.ecolind.2015.10.052.

Wickham, H. (2016). ggplot2: Elegant graphics for data analysis. Available at http://ggplot2.tidyverse.org. https://doi.org/10.1007/978-3-319-24277-4 